\title{
OPTICAL AND TRANSPORT PROPERTIES OF PVP-CH3 COOK SOLID POLYMER ELECTROLYTES
}

\author{
M. Seshu Kumar ${ }^{1,3}$, Sk. Shahenoor Basha ${ }^{2}$ and M. C. Rao ${ }^{3 *}$ \\ ${ }^{1,3}$ Department of Physics, Krishna University, Machilipatnam-521001, India \\ ${ }^{2}$ Department of Physics, Koneru Lakshmaiah Education Foundation, Guntur-522502, India \\ ${ }^{3}$ Department of Physics, Andhra Loyola College, Vijayawada- 520008, India \\ *E-mail: raomc72@gmail.com
}

\begin{abstract}
Solid polymer electrolyte films have been prepared with different wt $\%$ ratios of $\mathrm{PVP}-\mathrm{CH}_{3} \mathrm{COOK}$ by solution cast technique. Optical absorption studies were performed in the wavelength region from 200 to $800 \mathrm{~nm}$. The lowest energy bandgap value was found to be $3.25 \mathrm{eV}$ for the composition $80 \mathrm{PVP}: 20 \mathrm{CH}_{3} \mathrm{COOK}$. The ionic conductivity of the prepared films increases with increasing wt\% ratio of the salt in the PVP polymer. Transport properties of the prepared solid polymer electrolytes were calculated by Wagner's polarization technique. By using the prepared polymer films, solid polymer battery has been fabricated with the proposed wt $\%$ ratio and the discharge characteristics of the cell were calculated.

Keywords: Solid polymer electrolyte films, Solution cast technique, UV-visible, Wt\% composition, Transport properties and Discharge characteristics.
\end{abstract}

(C) RASĀYAN. All rights reserved

\section{INTRODUCTION}

In the present scenario, an attractive attention has been made towards solid polymer electrolytes due to their low production cost, excellent structural, thermal and electrochemical properties. Solid polymer films are expected to exhibit a major change in technological applications and industrial fields such as conductive coating, humidity sensors, microwave absorbing, energy storage devices and fuel cells ${ }^{1}$ etc. Solid polymer films are prepared by doping inorganic salt in the host polymer.

The mechanism of solid polymer electrolytes and their advantages were reported by Wright and Armand in $1970 \mathrm{~s}^{2,3}$. Due to the advantages of solid polymer electrolytes, these materials have taken a new development in the application of energy storage devices. The physical and electrochemical studies of polymer electrolytes bring a new revolution in the fields of energy storage applications ${ }^{4-8}$. The work on these polymer electrolytes has received a great attention which led a new way to the researchers for the development of applications such as batteries and electrochromic windows based on the fast ion movement ${ }^{9}$.

To obtain the solid polymer electrolyte with high ionic conductivity and improved mechanical stability, few factors have been taken into consideration. The solid polymer electrolytes must possess uniform surfaces with less brittle nature. The thickness of the films must be around 60 to $150 \mu \mathrm{m}$. By the complete dispersion of salt in the polymer, the improvement in ionic conductivity can be noticed in the polymer films. Nowadays researchers are making a tremendous effort for the development of rechargeable batteries based on potassium. Potassium is the alternative source of lithium. Potassium is less expensive than lithium and has a lot of advantages.

Potassium has greater abundance which can be used in the development of large-scale electricity storage on power grid systems. PVP is widely studied by the scientists and has been used in many applications due to its excellent potential performence ${ }^{10,11}$. Rao et al. published their results on different materials in the earlier studies ${ }^{12-55}$.

In the present study, an attempt was made for the preparation of films with polyvinyl pyrrolidone (PVP) and inorganic salt like potassium acetate with different wt\% composition ratios. 


\section{EXPERIMENTAL}

The chemicals such as PVP with a molecular weight (M.W: 36,000 g/mol), potassium acetate $\left(\mathrm{CH}_{3} \mathrm{COOK}\right)$ with $98 \%$ purity were purchased from Sigma Aldrich chemicals, India. The films were prepared by using solution cast technique by doping with inorganic salt (potassium acetate) in the host PVP polymer and labeled as different ratios (95:5), (90:10), (85:15) and (80:20). In the preparation process, double distilled water was used as a solvent. The proposed wt $\%$ ratios of chemicals were taken in a beaker with solvent and allowed to stir for 24 hours to obtain a homogeneous solution. After, the solution was taken in dishes and kept in a hot air oven at $60{ }^{\circ} \mathrm{C}$. Later the prepared films were placed in a vacuum desiccator.

\section{Optical Absorption Studies}

\section{RESULTS AND DISCUSSION}

Optical absorption spectra of the prepared solid polymer films with different wt $\%$ ratios have been recorded in the wavelength ranging from 200 to $800 \mathrm{~nm}$ is shown in Fig.-1. From the spectra, it has been observed that the optical absorption for all the films seems to be decreased with increase in wavelength. An excitation peak has been observed in the optical absorption spectra at $370.52 \mathrm{~nm}$. This may be due to inorganic salt which is dispersed in the polymer chains where the clusters are formed between the ions and the polymer matrix ${ }^{56,57}$. The decrement in the wavelength region has been observed. This may be due to the presence of dopant inorganic salt in the polymer matrix.

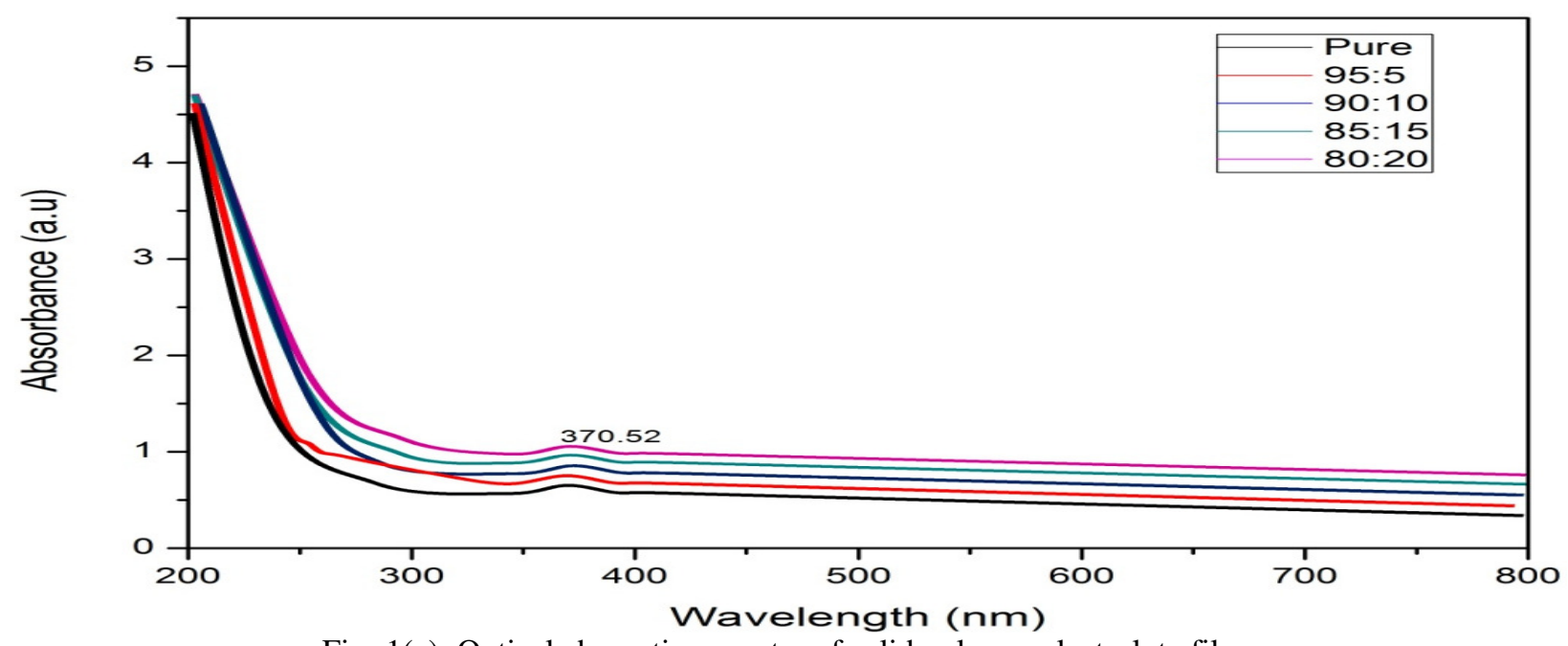

Fig.-1(a): Optical absorption spectra of solid polymer electrolyte films

From the Fig.-1(a), it is clearly observed that with increasing of wt $\%$ of the salt ratio in the host polymer matrix, the absorption values are decreased. This change may be due to the cluster bond formation between the salt ions and the polymer chains and also doping of nanofiller will affect the decrement of transmitting radiation. At shorter wavelengths, the electrons will be excited to the high energy state and occupy in the vacant positions of energy bands ${ }^{58,59}$. Thus the energy values are decreased.

Optical absorption coefficient ' $\alpha$ ' is calculated by the following equation,

$$
\alpha=2.303(\mathrm{~A} / \mathrm{t})
$$

Where, ' $\mathrm{A}$ ' is the absorbance and ' $\mathrm{t}$ ' is the thickness of the film

During the transmission radiation, the excitation of electrons in the valence band is equal to the excitation of electrons in the conduction band due to insufficient energies at low energy levels (direct bandgap), whereas at higher energy levels (indirect band gap) the excitation of electrons in the valence band is not equal to the excitation of electrons in the conduction band ${ }^{60,61}$. Absorption coefficient values can be determined by plotting a graph between $\alpha$ and hv. From the graph, it is evident that as the wt $\%$ of salt 
composition increases in the host polymer matrix by doping with an inorganic salt, the absorption coefficient decreases and the values are seen at 4.1, 4.15, 4.13, 4.12 and $3.75 \mathrm{eV}$.

Direct band gap transition is calculated by the following relation,

$$
\alpha h v=\mathrm{C}\left(\mathrm{hv}-\mathrm{E}_{\mathrm{g}}\right)^{1 / 2}
$$

Where, $\mathrm{E}_{\mathrm{g}}$ is the energy band gap, $\mathrm{C}$ is a constant value.

Direct band gap values are found to be at 4.21, 4.15,4.13, 4.12and $4.10 \mathrm{eV}$.

Indirect energy band gap values can be calculated by the following relation,

$\alpha h v=A\left(h v-E_{g}-E_{p}\right)^{2}+B\left(h v-E_{g}-E_{p}\right)^{2}$

Where, A and B are constants. Indirect band gap values are obtained from the graph by plotting $(\alpha \mathrm{hv})^{1 / 2} \mathrm{vs}$ hv as shown in Fig.-1(b) and the indirect band gap values are at 3.51, 3.42, 3.38, 3.29 and 3.26 respectively.

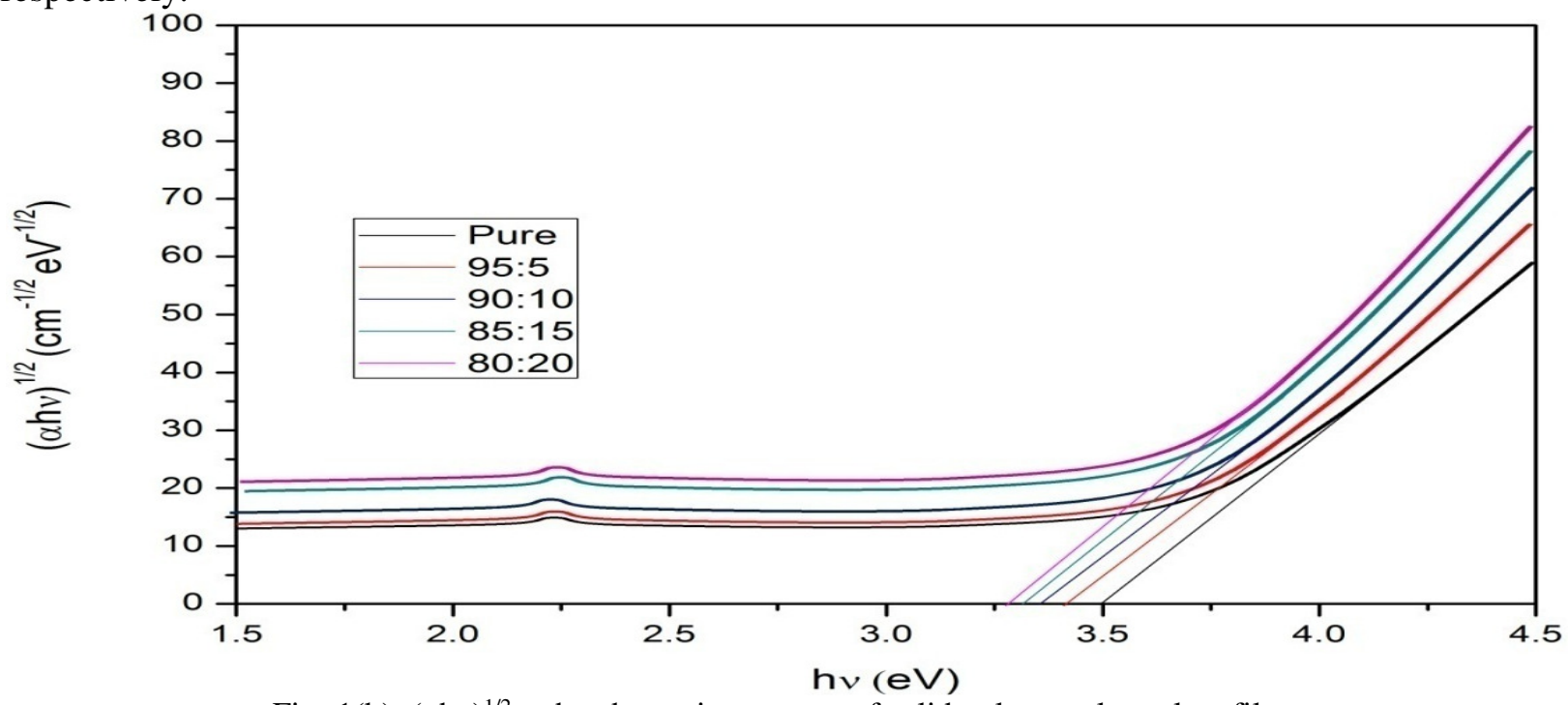

Fig.-1(b): $(\alpha h v)^{1 / 2} v s$ hv absorption spectra of solid polymer electrolyte films

From the direct and indirect band gap values, the optical absorption energy values are found to decrease continuously while doping $\mathrm{CH}_{3} \mathrm{COOK}$ in the host PVP polymer at different wt\% concentrations. Among all the obtained energy band gap values, the wt\% ratio (80:20) has the lowest band gap energy value which clearly indicates the enhancement of the ionic conductivity.

\section{Wt Percentage Composition Studies}

The wt\% composition studies with different ratios of PVP- $\mathrm{CH}_{3} \mathrm{COOK}$ have shown in Fig.-2. From the figure the enhancement of ionic conductivity has been observed by increasing the wt $\%$ ratio of the salt in the host PVP polymer and found to be higher for 80:20 composition ratio of the sample. The enhancement of ionic conductivity may be due to the miscibility of dopant salt in the polymer which increases the amorphous nature of the film ${ }^{62}$. The complete miscibility of the salt in PVP polymer results in the increment of the charge carriers which give rise to the enhancement of the ionic conductivity ${ }^{63}$. From the figure, the higher value of ion conductivity for composition $80 \mathrm{PVP}-20 \mathrm{CH}_{3} \mathrm{COOK}$ is found to be $2.31 \times 10^{-5} \mathrm{~S} \mathrm{~cm}^{-1}$.

\section{Transference Number}

Transport property is defined as the ratio of transference number of any particle/ion to total conductivity $\left(\sigma_{\mathrm{T})}\right.$. The transport properties have been calculated by the following equations using Wagner's polarizing technique and are presented in Table-1. 
RASĀYAN J. Chem.

Vol. 11 | No. 2 |613-619 | April - June | 2018

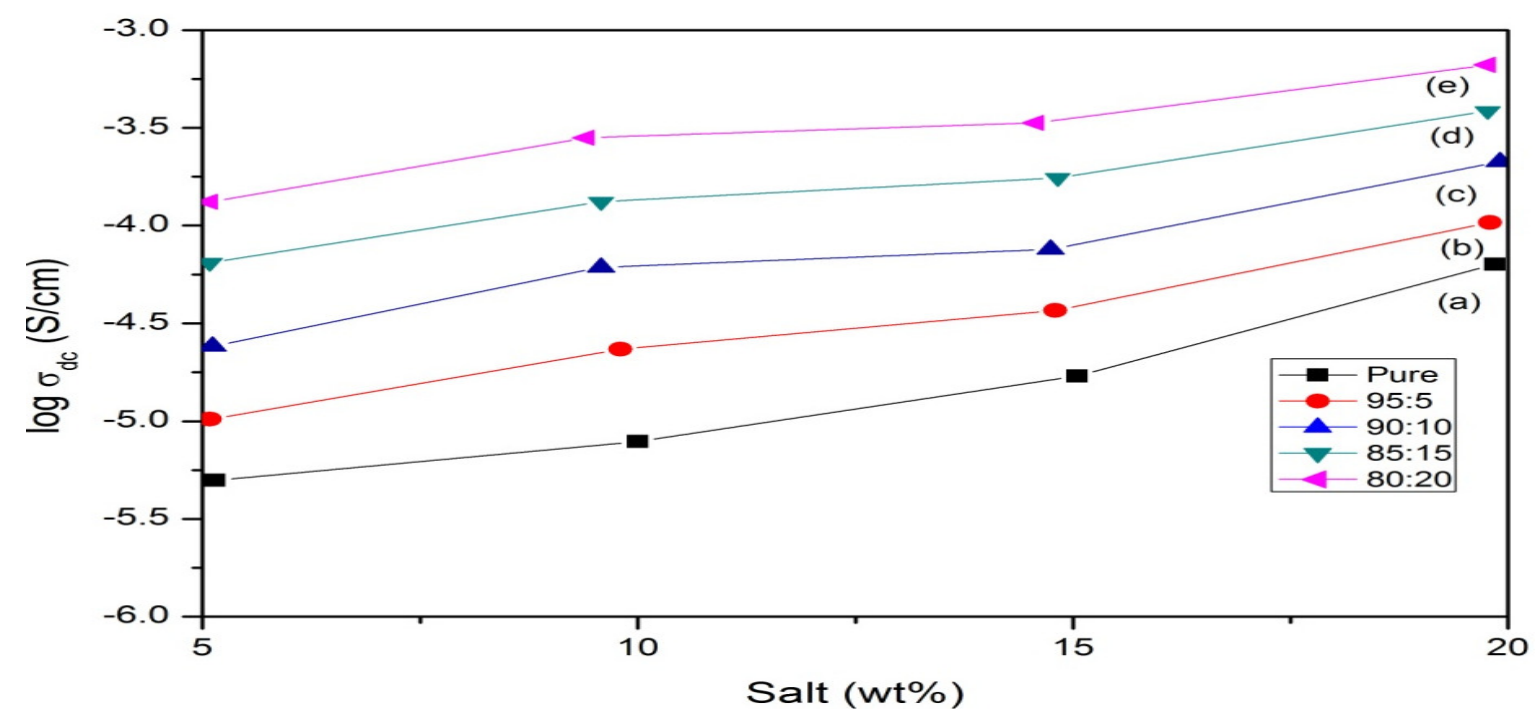

Fig.-2: wt $\%$ composition studies of solid polymer electrolytes

Table -1: Transport properties of solid polymer electrolytes

\begin{tabular}{c|c|c}
\hline \multirow{2}{*}{ Solid polymer films } & \multicolumn{2}{|c}{ Transference number } \\
\cline { 2 - 3 } & $\mathrm{t}_{\text {ion }}$ & tele \\
\hline Pure PVP & -------- & -------- \\
\hline PVP:CH ${ }_{3}$ COOK (95:5) & 0.95 & 0.05 \\
\hline PVP:CH $\mathrm{CH}_{3}$ COOK (90:10) & 0.96 & 0.04 \\
\hline PVP: $\mathrm{CH}_{3}$ COOK (85:15) & 0.97 & 0.03 \\
\hline PVP: $\mathrm{CH}_{3}$ COOK (80:20) & 0.98 & 0.02 \\
\hline
\end{tabular}

The total conductivity is given by:

$\sigma_{\mathrm{T}}=\frac{\sigma_{\text {ion }}+\sigma_{\text {ele }}}{\sigma_{\text {hole }}}$

The ionic transference number is given by:

$t_{i o n}=\frac{\sigma_{i o n}}{\sigma_{T}}$

and the electronic transference number is given by:

$t_{\text {ele }}=\frac{\sigma_{\text {ele }}}{\sigma_{T}}$

Of all wt\% ratios of $\mathrm{PVP}-\mathrm{CH}_{3} \mathrm{COOK}$ polymer electrolyte films, the sample with 80:20 wt $\%$ ratio has the high transfer of ions and it was found to be 0.98.The current with respect to time plot is shown in Fig.-3.

Initially, polarization and the current $\left(i_{t}\right)$ rises up followed by immediate decay of current and attain steady state after a long time of polarization have been observed. This may be due to the current initially flows across the cell at the blocking electrode under the influence of an applied voltage ${ }^{64-66}$.

The ionic transference values are obtained between 0.95 and 0.98 . This clearly shows that among all the wt \% ratios of samples, the majority transfer of ions 0.98 and minority of electrons 0.02 are found for (80:20) wt\% composition.

Fabrication of Solid-State Battery

A solidpolymer battery was prepared at room temperature. In this configuration, the diffusion of ions takes place through potassium metal which acts as an anode and the replacement of ions have been done through a mixture of iodine, electrolyte traces and carbon powder which act as a cathode material, where 
the charge carriers take place freely and hence the ionic conductivity increases ${ }^{67}$. The discharge characteristics of the prepared solid state battery and the performance have shown in Fig.-4.

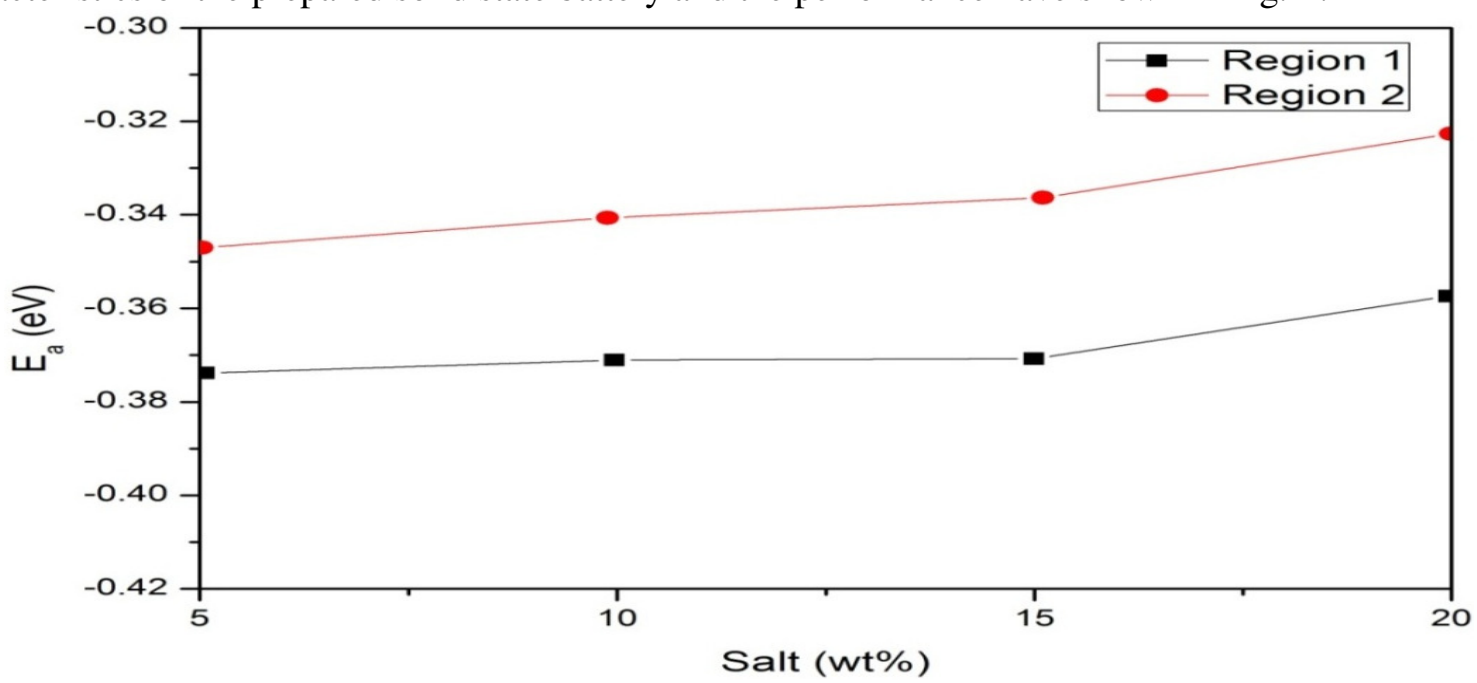

Fig.-3: Transport properties of solid polymer electrolyte films

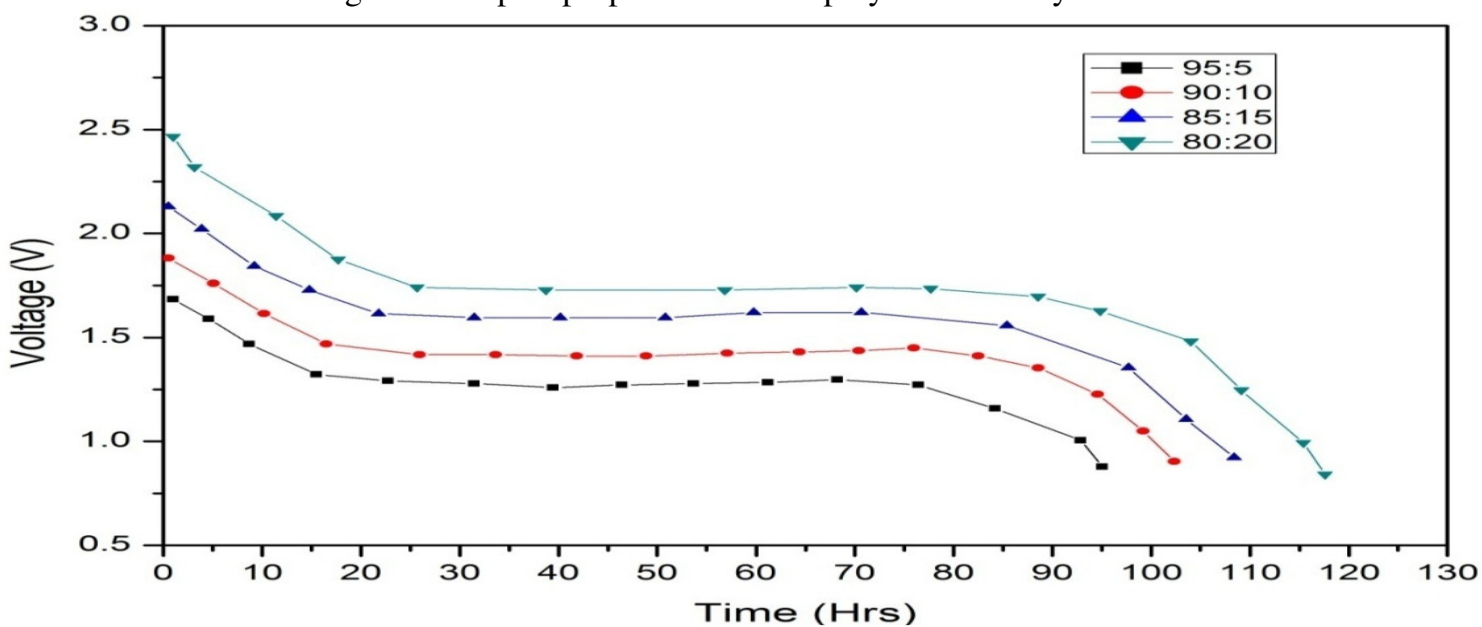

Fig.-4: Discharge characteristics of solid polymer electrolyte films

At first, the decrement in the voltage has been observed; this may be due to the polarization of current in an electrolyte and formation of a thin layer of potassium salt between the electrode-electrolyte interfaces. On comparison of all the wt $\%$ ratios, the polymer battery with the composition of [PVP: $\mathrm{CH}_{3} \mathrm{COOK}$ ] (80:20) exhibits better performance and found to have the higher stability up to $120 \mathrm{Hrs}$ than the other cells.

\section{CONCLUSION}

Solid polymer films have been prepared with different wt $\%$ ratios of PVP: $\mathrm{CH}_{3} \mathrm{COOK}$ by solution cast technique. Optical absorption and energy band gap values were decreased due to the cluster bond formation between the salt ions and the polymer chains. This may be due to the doping of salt will affect in the decrement of transmitting radiation. From the wt\% composition studies the higher value of ion conductivity for composition $80 \mathrm{PVP}-20 \mathrm{CH}_{3} \mathrm{COOK}$ as found to be $2.31 \times 10^{-5} \mathrm{~S} \mathrm{~cm}^{-1}$ at $373 \mathrm{~K}$. The Discharge characteristics of the polymer battery showed better performance and stability up to $120 \mathrm{Hrs}$.

\section{REFERENCES}

1. P.V. Wright, Br. Polym. J., 7, 319 (1975).

2. M.B. Armand, J.M. Chabango and M.J. Duclot, in Fast Ion Transport in Solids, North-Holland, Amsterdam, 1979, p. 131. 
3. D.E. Fenton, J.M. Parker and P.V. Wright, Polym., 14, 589 (1973).

4. Sk. Shahenoor Basha, M. Gnanakiran, B. Ranjit Kumar, K. Veera Bhadra Reddy, M.V. Basaveswara Rao and M.C. Rao, Rasayan J. Chem., 10 (4), 1159 (2017), DOI:10.7324/RJC.2017.1041756

5. Ch. V. Subba Reddy, A. K. Sharma and V. V. R. Narasimha Rao, Ionics, 10 (1-2), 142 (2004).

6. R. Nadimicherla, A.K. Sharma, V. V. R. Narasimha Rao and W. Chen, Ionics, 21(6), 1587 (2015).

7. K. Kiran Kumar, M. Ravi, Y. Pavani, S. Bhavani, A.K. Sharma and V.V.R. Narasimha Rao, J. Memb. Sci., 454, 200 (2014).

8. C. VenkataSubba Rao, M. Ravi, V. Raja, P. Balaji Bhargav, A.K. Sharma and VVR. Narasimha Rao, Iran Polym. J., 21, 530 (2012).

9. M.B. Armand, Ann. Rev. Mater. Sci., 16, 245 (1986).

10. S. Chandra, S.A. Hashmi and G. Prasad, Solid State Ionics, 40, 651 (1990).

11. M. Kumar and S.S. Sekhon, Ionics, 8, 223 (2002).

12. SK. Shahenoor Basha, K.V. Kumar and M.C. Rao, J. Inorg. Organomet. Polym., 27, 455 (2017), DOI:10.1007/s10904-016-0487-3

13. M.C. Rao, J. Crys. Growth, 312(19), 2799 (2010), DOI:10.1016/j.jcrysgro.2010.06.012

14. M.C. Rao, J. Optoelect. Adv. Mater., 13, 428 (2011).

15. SK. Shahenoor Basha and K. Vijaya Kumar, Int. J. ChemTech Res., 8, 803 (2015).

16. M.C. Rao, Eur. Phys. J. Appl. Phys., 48(2), 20503 (2009), DOI: 10.1051/epjap/2009142

17. M.C. Rao, J. Optoelect. Adv. Mater., 12, 2433 (2010).

18. M.C. Rao, O. M. Hussain, Ind. J. Eng. Mater. Sci., 16, 335 (2009).

19. P. Prasad and M.C. Rao, J. Mol. Struc., 1085, 115 (2015), DOI:10.1016/j.molstruc.2014.12.086

20. M.C. Rao, Optoelect. Adv. Mater. (Rapid Commun.), 5(5-6), 651 (2011).

21. M.C. Rao and O.M. Hussain, Optoelect. Adv. Mater., 13(2-4), 1109 (2011).

22. M. P. D. Parimala, M. Seshu Kumar and M.C. Rao, Rasayan J. Chem., 10(3), 825 (2017).

23. M.C. Rao, J. Optoelect. Adv. Mater., 13(1-2), 72 (2011).

24. M.C. Rao, Int. J. Chem. Sci., 10(2), 1111 (2012).

25. M.C. Rao, Optoelect. Adv. Mater. (Rapid Commu.), 6, 511 (2012).

26. M. Tejaswi and M.C. Rao, Rasayan J. Chem., 9(4), 697 (2016).

27. K. Koteswara Rao, Rasayan J. Chem., 10(3), 904 (2017), DOI: 10.7324/RJC.2017.1031745

28. M.C. Rao, J. Optoelect. Adv. Mater., 13, 78 (2011).

29. M.C. Rao and Sk. Muntaz Begum, Optoelect. \& Adv. Mater. (Rapid Commu.), 6, 508 (2012).

30. M.C. Rao, Optoelect. Adv. Mater. (Rapid Commun.), 4, 2088 (2010).

31. M.C. Rao and O.M. Hussain, Optoelect. Adv. Mater. (Rapid Commu.), 6, 245 (2012).

32. K. Ravindranadh and M.C. Rao, Int. J. ChemTech Res., 9(4), 598 (2016).

33. M.C. Rao, Res. J. Rec. Sci., 2(3), 67 (2013).

34. M.C. Rao and O.M. Hussain, Res. J. Chem. Sci., 1(7), 76 (2011).

35. M.C. Rao, J. Non-Oxide Glasses, 5, 1 (2013).

36. M.C. Rao, AIP Conf. Proc., 1728(1), 020077 (2016).

37. G. Sunita Sundari, Rasayan J. Chem., 10(1), 298 (2017), DOI: 10.7324/RJC.2017.1011621

38. M.C. Rao, AIP Conf. Proc., 1536(1), 215 (2016).

39. M.C. Rao, Optoelect. Adv. Mater. (Rapid Commu.), 6, 245 (2012).

40. M.C. Rao, Optoelect. Adv. Mater. (Rapid Commun.), 10, 889 (2016).

41. T. Samuel, K. Ramachandra Rao and M.C. Rao, AIP Conf. Proc., 1728(1), 020080 (2016)

42. M.C. Rao, Int. J. Pure Appl. Phys., 6, 365 (2010).

43. M.C. Rao and Sk. Muntaz Begum, AIP Conf. Proc., 1447, 613 (2012).

44. K. Lakshmi, SK. Shahenoor Basha and M.C. Rao, Rasayan J. Chem.,10(2), 682 (2017), DOI: 10.7324/RJC.2017.1021744

45. M.C. Rao, AIP Conf. Proc., 1447, 613 (2012). 
46. M.C. Rao, AIP Conf. Proc., 1536, 27 (2013), DOI:10.1063/1.4810083

47. M.C. Rao, J. Alloys Compd., 491, 503 (2010), DOI:10.1016/j.jallcom.2009.10.246

48. M.C. Rao, Optoelect. Adv. Mater. (Rapid Commun.), 5, 85 (2011).

49. Sk. Muntaz Begum, M.C. Rao and K. Ravindranadh, AIP Conf. Proc. 1349, 641 (2011).

50. K. Ravindranad and M.C. Rao, AIP Conf. Proc.1536, 215 (2013), DOI: 10.1063/1.4810177

51. M.C. Rao and K. Ravindranadh, Mater. Res. Innovations 21(2), 102 (2017).

52. Sk. Shahenoor Basha, Rasayan J. Chem.10, 279 (2017), DOI: 10.7324/RJC.2017.1011612

53. M.C. Rao, J. Polym. Sci. Series A 59(4), 554 (2017), DOI: 10.1134/S0965545X17040095

54. M.C. Rao, J. Optoelecctron. Biomed. Mater. 5(1), 9 (2013).

55. K. Ravindranadh, R.V.S.S.N. Ravikumar and M.C. Rao, J. Non Oxide Glasses, 5, 39 (2013).

56. S. Selvasekarapandian, M. Hema, J. Kawamura, O. Kamishima and R. Baskaran, J. Phys. Soc., Jpn. Suppl. A79, 163 (2010).

57. R. Naveen and M.C. Rao, Rasayan J. Chem., 11, 195 (2018), DOI: 10.7324/RJC.2018.1112016

58. T. Sreekanth, M. Jaipal Reddy and U.V. Subba Rao, J. Power Sources, 93, 268 (2001).

59. B.B. Owens, W.H. Smyrl and J.J. Xu, J. Power Sources, 150, 81 (1999).

60. G.P. Pandey, R.C. Agrawal and S.A. Hashmi, J. Solid State Electrochem., 15, 2253 (2012), DOI: 10.1007/s10008-010-1240-4

61. X.F. Yang, G.C. Wang, R.Y. Wang and X.W. Li, Electrochem. Acta, 55, 5414 (2010).

62. T.D. Gregory, R.J. Hoffmann and R.C. Winterton, J. Electrochem. Soc., 137, 775 (1990).

63. C.W. Liew and S. Ramesh, J. Mater. Res., 27, 2996 (2012).

64. S. Rajendran, R. Sankar Babu and P. Siva Kumar, J. Membrane Sci., 315, 67 (2008).

65. K. NareshKumar, M. Jaipal Reddy and U.V. Subba Rao, J. Power Sources, 101, 130 (2001).

66. K. Murata, Electrochem. Acta, 40, 2177 (1995).

67. A. Chandra, R.C. Agrawal and Y.K. Mahipal, J. Phys. D: Appl. Phys., 42, 1 (2009), DOI:10.1088/1367-2630/10/4/043023

[RJC-2082/2018] 